\title{
Introduction to Cleaner Production in Jeans SME at Jeans Center of Surobayan, Wonopringgo, Pekalongan Regency of Indonesia
}

\author{
Edy Suhartono ${ }^{1}$, S Setyowati Rahayu ${ }^{2}$, Basuki Setyobudi ${ }^{1}$, and Muhammad Yusa ${ }^{3}$ \\ ${ }^{1}$ Department of Civil Engineering, State Polytechnic of Semarang, Indonesia \\ 2 \\ Department of Mechanical Engineering, State Polytechnic of Semarang, Indonesia \\ 3 Department of Informatics, State University of Bengkulu, Indonesia
}

\begin{abstract}
The development of the jeans industry in Pekalongan Regency is very rapid, due to being one of the convection centres in Central Java. One of the jeans centres is reported to be located at Surobayan, Wonopringgo, Pekalongan Regency. Prior to 2019, the condition of the jeans centre in Pekalongan Regency developed naturally. Based on the labour adsorption ability, the jeans convection industry ranks second after batik crafts. Also, this industry is reported to have potentials in creating more than 1680 labour in Surabayan, Wonopringgo, Pekalongan Regency.
\end{abstract}

Based on improving the economic, social, and environmental performance of Jeans Centre at Surabayan, the implementation of clean sustainable production tools and minimization of liquid waste disposal through the (3R) pattern, is carried out. The production of the convection industry is in the form of jeans as well as pants for both adults and children. Also, the production capacity of each jeans convection craftsman per month, is observed to be ranging from 300 to 1200 scores.

Based on implementing a sustainable clean production, the company has to take several steps, which includes identifying the causes of inefficiency, analyzing societal symptoms and impacts, determining the necessary stages for improving environmental management, as well as integrating and evaluating them (the stages) into the company's organizational structure.

Keywords: Clean Production, Efficiency, Environmental Management.

\section{INTRODUCTION}

The current application of environmetal management tools in an integrated and systematic manner is one of strategies utilized by companies towards achieving a balance economic, and social environment. These integrated and systematic efforts include the provision of conducive government policies and programs, and use of best environmental management practices. This is in addition to adequate use of environmental management infrastructure in the form of education and training packaged in implementing PPPUD (Regional Leading Product Development Program). In Pekalongan Regency, especially the Surabayan Jeans Center, Wonopringgo, SME grows yearly irrespective of the closure of a significant number of businesses. On average, a company has 15 employees and annually uses 182,880 m of jeans, $16001 \mathrm{of}_{2} \mathrm{O}_{2}, 2000 \mathrm{~kg}$ of coustic, and $200 \mathrm{~kg}$ of teepol.

The production process of jeans requires an average of $15,000 \mathrm{~L}$ of water and $30 \mathrm{~m}^{3}$ of firewood. Meanwhile, it manufactures failed 914 m products, $80 \%$ wastewater, $50.4 \mathrm{~kg}$ coloring agent, and scattered $\mathrm{H}_{2} \mathrm{O}_{2}$, coustic, and teepol of $200 \mathrm{~L}, 24 \mathrm{~kg}$, and $10 \mathrm{~kg}$, without the use of natural dyes (Suhartono, 2019). This condition negatively affects to the environment and the company assuming that the management is not carried out in an integrated manner. Therefore, efforts to manage the environment and sav e raw materials, additives, water, and energy are still faced with constraints due to a lack of practical knowledge on environmental management and limited human resources.

Therefore, to increase these potentials, the implementation of sustainable clean production was carried out at this center. Through the application of clean sustainable production, the volume of wastewater is reduced during the production process, with a decrease in pollutants by the use of environmentally friendly materials. The development of wastewater and pollutant volume leads to a decrease in the need for pollutant and wastewater treatment costs. The steps needed for the implemetation of sustainable clean production are as follows. Identifying the causes and efficiency required to analyze environmental causes and impacts, 
Inte rnational Journal of Advances in Scientific Research and Engineering (ijasre), Vol 7 (7), July -2021

determining the necessary steps for enhancing environmental management, integrating these steps in the company's organizational structure, and evaluation.

\subsection{Problem}

a. The existence of Non-Product Output (NPO) is in the form of material, energy, and water with a wasted range of 10-30\% of the total cost of production.

b. The non-optimal strategy for clean sustainable production with economic efficiency in the production process and improved services reduced the use of natural resources as well as toxic and hazardous materials.

\subsection{Activity Objectives}

a. Evaluating energy efficiency calculations in the Jeans Industry

b. Compiling the potential for energy efficiency in the Jeans Industry

c. Evaluating energy use which can be optimized in such a way as to obtain a high level of efficiency and be environmentally friendly

\subsection{Activity Benefits}

a. Understanding the level of energy efficiency in the Jeans Industry

b. Discerning the potential for energy efficiency in the Jeans Industry

c. Determining the energy use that can be optimized in such a way to obtain a high level of efficiency and be environmentally friendly

\section{LITERATURE REVIEW}

\subsection{General}

Clean Production: A preventive and integrated environmental management strategy is continuously applied to production processes, products, and services to increase eco-efficiency and reduce risks to humans and the environment (UNEP). Initially, environmental management was based on a carrying capacity approach due to the limited natural ability to neutralize the increasing pollution. Efforts in overcoming the pollution problem have turned into an end of pipe treatment approach.

\subsection{Clean Production Concept}

This concept consists of a hierarchy method used to directly carry out the in-pipe recycling process. Therefore, solving environmental problems is emphasized on the source of pollution not at the end of the process as in the end-of-pipe treatment technology. This includes the efficient use of natural resources which also means a reduction of waste generated, pollution, as well as risks to human health and safety. Furthermore, this concept does not always require expensive activities or sophisticated technology rather it often leads to potential savings thereby increasing competitiveness in the market. Therefore, a change in attitude, responsible environmental management, and an assessment of technology choices is needed. One of the clean productions that are simple to be implemented is good housekeeping.

\subsection{Clean Production Steps}

\section{1). Substitution of Raw and Auxiliary Materials}

a. Replacing hazardous raw materials with less hazardous and less toxic materials (B-3)

b. Replacing solvents and cleaning agents that contain hazardous materials.

\section{2). Repairing the Household System}

a. Reducing the loss of raw materials, products, and energy due to leaks and spills.

b. Positioning equipment properly to avoid spills and contamination.

c. Providing and using storage for drops, spills, and leaks.

d. Preventing the mixing of waste streams from different sources.

\section{3) Product Modifications}

a. Replacing damaged equipment and repairing its layout to optimize material flow and product efficiency.

B .Improving process conditions such as flow rate, temperature, pressure, and storage time, to enhance the quality of the final product and reduce waste generation.

\section{4) Process Modification}

a. Replacing damaged equipment and repairing its layout to optimize material flow and product efficiency. 
b. Improving process conditions such as flow rate, temperature, pressure, and storage time, to enhance the quality of the final product and reduce waste generation.

\subsection{Advantages in implementing Clean Production}

a. Increasing efficiency.

b. Reducing Waste Treatment Costs.

c. Conserving Raw Materials and Energy.

d. Assisting Access to Financial Institutions.

e. Fulfilling Market Demand.

f. Improving Environmental Quality.

g. Fulfilling Environmental Regulations.

h. Improving the Work Environment.

i. Increasing Public Perception.

\section{RESEARCH METHODOLOGY}

1) Library Studies: This study was conducted to obtain reference sources that can be used as a reference in its preparation.

2) Data collection methods: secondary and primary data were obtained from related agencies, and field surveys, respectively.

3) Data analysis and processing techniques: the secondary data and existing information obtained from related agencies in the previous stage were analyzed using descriptive analysis. In this stage, an overview of the performance conditions of the batik industry in Simbang | Kulon, such as an analysis on the level of material and energy use, and the volume level of waste discharged into the environment are obtained.

4) Developing a Correlation Model which can be used to determine factors that influence (determinants) the successful management of the jeans industry in an efficient and environmentally friendly manner (eco-efficiency).

5) Developing a Forecasting/Regression Statistical Model, used to forecast important indicators and be used as material for future planning.

\section{CONCLUSION}

a. The layout of Ryan Jeans SME in accordance with the implementation of clean production

b. Hot Spots of Ryan Jeans SME on jeans cutting, washing, and ironing as well as a drug store.

c. Analysis of the causes and alternative steps for each SME in implementing clean production.

d. NPO calculation before and after the application of net production.

\section{ACKNOWLEDGMENTS}

The authors are grateful to the Ministry of Education, Research and Technology and the Director of the Semarang State Polytechnic for the opportunity given to carry out Community Service activities in this third year.

\section{REFERENCES}

1. Energy Conservation in the Textile Industry. United Nations Industrial Development Organization (UNIDO) and Ministry of International Trade and Industry. (MITI), Japan 1992

2. Suhartono, E et al, 2019, Final Report on PPPUD Blue Jeans Surabayan ion Export Efforts Through Environmental Management Cleaner, Green Product and Ecoefficiency In Surabayan Wonopringgo District, District Pekalongan

3. Sustainable Development Program. January 1998. http://www.unido.org/ssites/env/sectors/sectors701.html. 
International Journal of Advances in Scientific Research and Engineering (ijas re), Vol 7 (7), July -2021

4. The Textiles Industry: Improvement of Resource Efficiency and Environmental Performance. CleanerProduction.com, Hamner and Associates LLC, 2000,

5. http $/ /$ www.cleanerproduction.com/industries/textiles.html.

6. UNEP Textiles Working Group on Cleaner Production, http://www.emcentre.com/textile/index.htm 